\title{
RECENT EXTRA-LIMITAL BREEDING RECORDS OF THE RED-NECKED GREBE IN THE ROSETOWN-BIGGAR DISTRICT OF SASKATCHEWAN
}

\author{
WAYNE E. RENAUD, 9 Oakwood Avenue N., Mississauga, ON L5G 3L6, \\ ROBERT A. WAPPLE, 740 4th Street E., Saskatoon, SK S7N 1K2, and \\ GUY J. WAPPLE, 322 Gillam Crescent, Saskatoon, SK S7N 3R9
}

\section{Introduction}

Birds of Canada shows the Saskatchewan breeding range of the Red-necked Grebe as covering approximately $85 \%$ of the province, absent only in the extreme northeast and extreme south.' In contrast, Smith's Atlas of Saskatchewan Birds, which is based on more recent, and many unpublished, records shows the area of confirmed breeding records as a somewhat narrower band that cuts diagonally across the province between the Aspen Parkland ( Smith's 'Aspen Woodland Subregion') in the southeast and the Churchill River Subregion of the Northern Boreal Region with an outlying pocket in the Cypress Hills region." The habitats of the RosetownBiggar area fall within both the upper portions of the Mixed Prairie (Smith's 'Moist Mixed Prairie Subregion') and lower portions of the Aspen Parkland (Figure 1). Immediately to the east, in the Saskatoon area, which exhibits mostly Aspen Parkland, the first recorded Red-necked Grebe nesting occurred at Pike Lake (two adults with three young) in 28 July 1962 , but today the species is still considered as an "uncommon transient and summer resident". 2,3

Northeast and southwest of the known breeding range in Saskatchewan, not only is the species rare or absent as a confirmed breeder, it is surprisingly also rare or absent as a transient. " For example, in the Elbow area, Roy regarded the species as an "irregular transient and summer resident: possibly breeds" with the only summer records of non-breeding pairs, both on 17
June 1989, occurring at Broderick Reservoir and the Spring Lakes. ${ }^{5}$

When Birds of the Rosetown-Biggar District, Saskatchewan was published in 1975, there were no historic records, and only two spring migration records of Rednecked Grebes from 1965 to 1975: one swimming near a bulrush marsh locally known as Middle Van Scoy Lake $(6 \mathrm{~km} \mathrm{nw}$ of Perdue, \#1 in Table 1 and Figure 1) on 25 May 1972, and two seen and heard calling on Upper Van Scoy Lake (\#2) on 21 May 1975. The parting comment in the species account was "although the location offered what appeared to be ideal breeding habitat, no Red-necked Grebes were seen during later visits to the marshes." 4

\section{Spring and breeding season records since 1975}

Records for the regions west and north of the 1975 study area come primarily from two sources : observations by William and Ernest Jasper of the Struan area in the 1940s to 1980s, and the annual Biggar Breeding Bird Survey from 1972 to the present. The authors have surveyed the area only sporadically from 1970 to 1997 and more intensively since the boundary of the new study area was expanded by Nature Saskatchewan in 1997 to include this area for the forthcoming revision of the book (see Map 1). In contrast, the Van Scoy Lake system (ie. Perdue Marsh, 'Lower' , 'Middle' and 'Upper Van Scoy Lake') has been birded an average of 15 


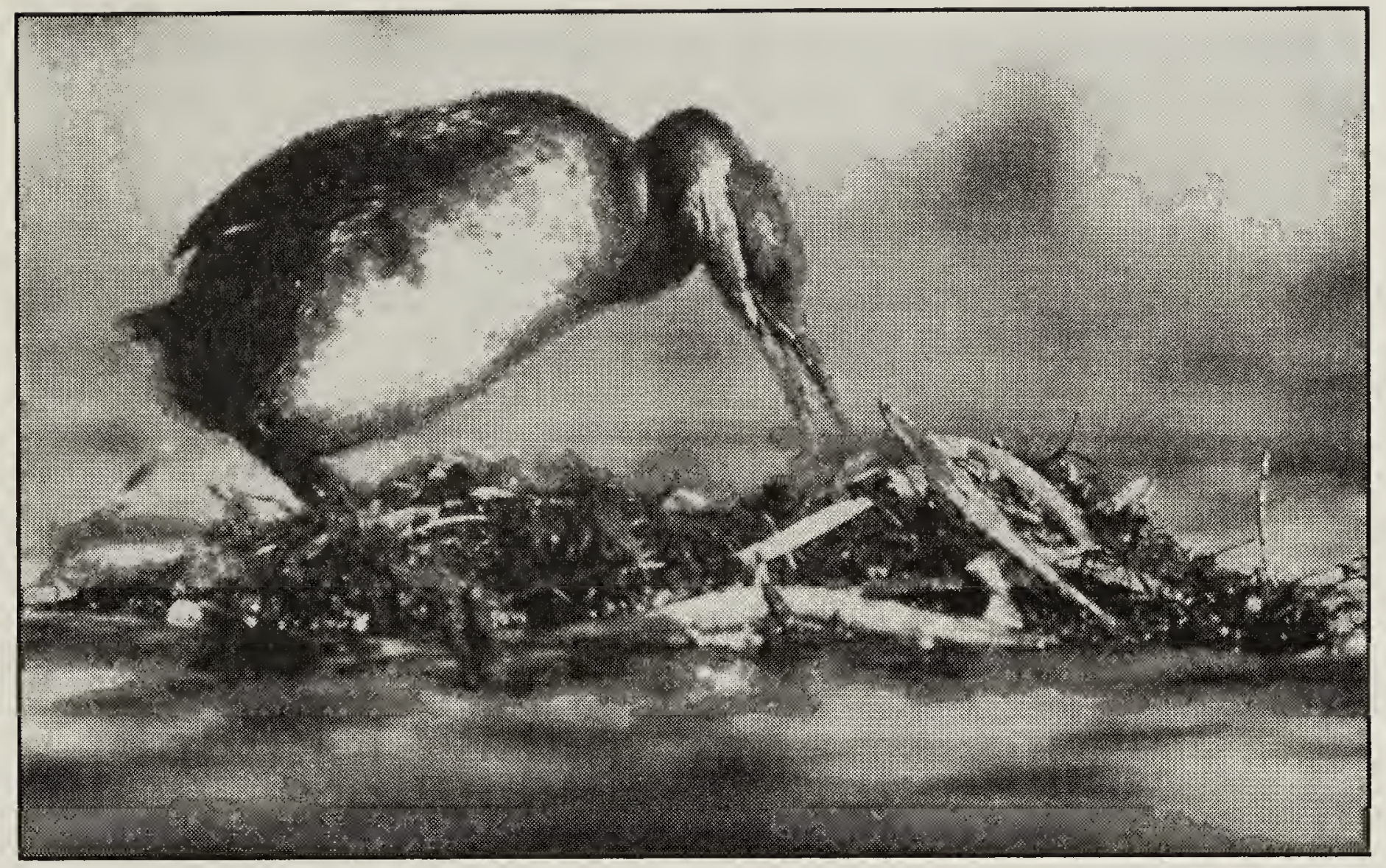

Red-necked Grebe on nest

Andrius Valadka

times each year from 1975 to the present by one or more of the authors.

To the north of the 1975 study area, William and Ernest Jasper's list of birds from the Struan area did not contain a single Rednecked Grebe record. Even within the bounds of the 1975 study area, Red-necked Grebes, until very recently, were recorded only sporadically. On 2 May 1976, Guy Wapple added a third record to the two already mentioned, a single bird swimming along the north shore of Middle Van Scoy Lake. No Red-necked Grebes were recorded in the 1980s. Between 1965 and 1996 no definitive breeding records had been established for this well-covered area.

In 1990, a single non-breeding bird was seen at 'Biggar Sewage Lagoon' (\#4) on 4 June; and on 16 June 1992, two birds were seen by Guy and Robert Wapple during the Biggar Breeding Bird Survey (\#5). At the latter location, no time could be spent looking for a nest, but the date and habitat provided the perfect setting for a breeding record.

In 1997, water birds in general had a very productive year because of above average snow melt and abundant spring rains. On 26 May 1997, Wayne Renaud finally found a Red-necked Grebe nest in the study area. The nest, containing one egg, was situated along the northeast shore of the Middle Van Scoy Lake (\#7) in a narrow band of sparse second-year bulrushes $10 \mathrm{~m}$ from the shoreline. Two grebes attended the nest; a third adult grebe was noted near a band of dead bulrushes $0.2 \mathrm{~km}$ south on the southeast edge of the lake (\#6).

On 3 June 1997, a pair attending a second nest was found on a 80-ha marsh $9.5 \mathrm{~km}$ west and $3.2 \mathrm{~km}$ south of Struan (\#8) (24 $\mathrm{km}$ nnw of Middle Van Scoy Lake). On 5 June, two more pairs of grebes, each attending a nest with an undetermined number of eggs, only $45 \mathrm{~m}$ apart, were found by Wayne Renaud and Wayne Harris in thin bulrushes near the shore of a perched reservoir $5.6 \mathrm{~km}$ east of Shrimp Lake $(8 \mathrm{~km}$ east and $4.8 \mathrm{~km}$ south of Herschel) $(\# 9, \# 10)$. One nest was located only $40 \mathrm{~m}$ from a welltravelled gravel road and the lake itself was surrounded by prairie and cultivated fields, the last place one would expect to find this species nesting. On 20 June, Guy Wapple heard one Red-necked Grebe calling from 
TABLE 1. RED-NECKED GREBE RECORDS IN THE ROSETOWN-BIGGAR DISTRICT, 1965-2000 Record numbers (Rec. No.) are transposed onto Figure 1.

[Codes and abbreviations: *: record from a Breeding Bird Survey: ad: adult: N: nest: e: egg: nf: newly fledged; B: brood; $y$ : young; square brackets indicate a repeat visit to an earlier location during the same year. Observers: WR=Wayne Renaud: $D R=D$ Don Renaud: $A R=A n n i e$ Renaud: $G W=$ Guy Wapple: RW=Roben Wapple; GT=George Tosh ; WH=Wayne Harris; SM=Sue MacAdam]

\begin{tabular}{|c|c|c|c|c|c|}
\hline$\frac{\text { vear }}{\text { Rec.No. }}$ & date & $\#$ ad/nest/brood & location & habitat & obs(s) \\
\hline 1972 & & & 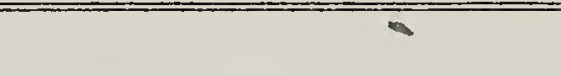 & & \\
\hline 1 & 25 May & $1 \mathrm{ad}$ & 'Middle Van Scoy Lake' & lake/marsh & WR/DR \\
\hline \multicolumn{6}{|l|}{1975} \\
\hline 2 & $21 \mathrm{May}$ & $2 \mathrm{ad}$ & 'Upper Van Scoy Lake' & alkali lake/marsh & GW \\
\hline \multicolumn{6}{|l|}{1976} \\
\hline$\overline{3}$ & 2 May & $1 \mathrm{ad}$ & 'Middle Van Scoy Lake' & lake/marsh & GW \\
\hline \multicolumn{6}{|l|}{1990} \\
\hline 4 & 4 June & $1 \mathrm{ad}$ & 'Biggar Sewage Lagoon' & slough/marsh & RW \\
\hline \multicolumn{6}{|l|}{1992} \\
\hline 5 & *16 June & $2 \mathrm{ad}$ & $7 \mathrm{~km} \mathrm{~s}$ of Struan & marsh & GW/RW \\
\hline \multicolumn{6}{|l|}{1997} \\
\hline \multirow[t]{4}{*}{$6 / 7$} & 26 May & $2 \mathrm{ad} / \mathrm{N} l \mathrm{e} ; 1 \mathrm{ad}$ & e end@ Middle Van Scoy Lake’ & lake/marsh & WR \\
\hline & [28 May & $2 \mathrm{ad} / \mathrm{Nle}$ & e end $a$ 'Middle Van Scoy Lake' & lake/marsh & WR] \\
\hline & [29 May & $1 \mathrm{ad} / \mathrm{NOe}$ & e end $a$ 'Middle Van Scoy Lake & lake/marsh & WR] \\
\hline & [2 June & $1 \mathrm{ad}$ & e end@'Middle Van Scoy Lake' & lake/marsh & RW] \\
\hline 8 & 3 June & $2 \mathrm{ad} / \mathrm{N} ? \mathrm{e}$ & $9.5 \mathrm{k} \mathrm{w}$ and $3.2 \mathrm{k} \mathrm{s}$ of Struan & marsh & WR/GW/RW \\
\hline $9 / 10$ & 5 June & $2 \mathrm{ad} / \mathrm{N} ? \mathrm{e} ; 2 \mathrm{ad} / \mathrm{N} ? \mathrm{e}$ & $5.6 \mathrm{~km}$ e of Shrimp Lake & freshwater lake & WR/WH \\
\hline 11 & *20 June & $1 \mathrm{ad}$ & Lizard Lake & lake & GW \\
\hline \multirow[t]{2}{*}{12} & 12 July & $3 \mathrm{ad} / \mathrm{Bnf} 3 \mathrm{y}$ & $5.6 \mathrm{~km}$ e of Shrimp Lake & freshwater lake & RW \\
\hline & [12 July & $2 \mathrm{ad}$ & Shrimp Lake & freshwater lake & $\mathrm{RW}]$ \\
\hline \multicolumn{6}{|l|}{1998} \\
\hline$\overline{13}$ & 11 June & $2 \mathrm{ad}$ & $6.5 \mathrm{~km}$ west of Springwater & lake/marsh & WR/GT \\
\hline 14 & *23 June & $1 \mathrm{ad}$ & $3 \mathrm{~km} w$ of Struan & unspecified & GW \\
\hline 15 & *23 June & $2 \mathrm{ad}$ & $5 \mathrm{~km}$ e of Struan & beaver pond & GW \\
\hline $16 / 17$ & 17 July & $1 \mathrm{ad} / \mathrm{B} 1 \mathrm{y} ; \mathrm{lad} / \mathrm{B} 2 \mathrm{y}$ & $6 \mathrm{~km} \mathrm{w} \mathrm{\&} 3 \mathrm{~km} \mathrm{~s}$ of Struan & marsh & RW \\
\hline \multicolumn{6}{|l|}{2000} \\
\hline \multirow[t]{3}{*}{18} & 13 July & $1 \mathrm{ad}$ & 'Middle Van Scoy Lake' & freshwater lake & WR/RW \\
\hline & [14 July & $1 \mathrm{ad}$ & 'Middle Van Scoy Lake' & freshwater lake & WR/GW] \\
\hline & [16 July & $1 \mathrm{ad}$ & 'Middle Van Scoy Lake' & freshwater lake & WR/AR] \\
\hline 19 & 17 July & $\mathrm{lad} / \mathrm{B} 3 \mathrm{y}$ & $5 \mathrm{k}$ ne of Cando & marsh & WH/SM \\
\hline 20 & [18 July & 1 ad & $5.6 \mathrm{~km}$ e of Shrimp Lake & freshwater lake & GW] \\
\hline
\end{tabular}


MAP 1: RED-NECKED GREBE RECORDS IN THE ROSETOWN-BIGGAR DISTRICT. Numbers correspond to those in Table 1.

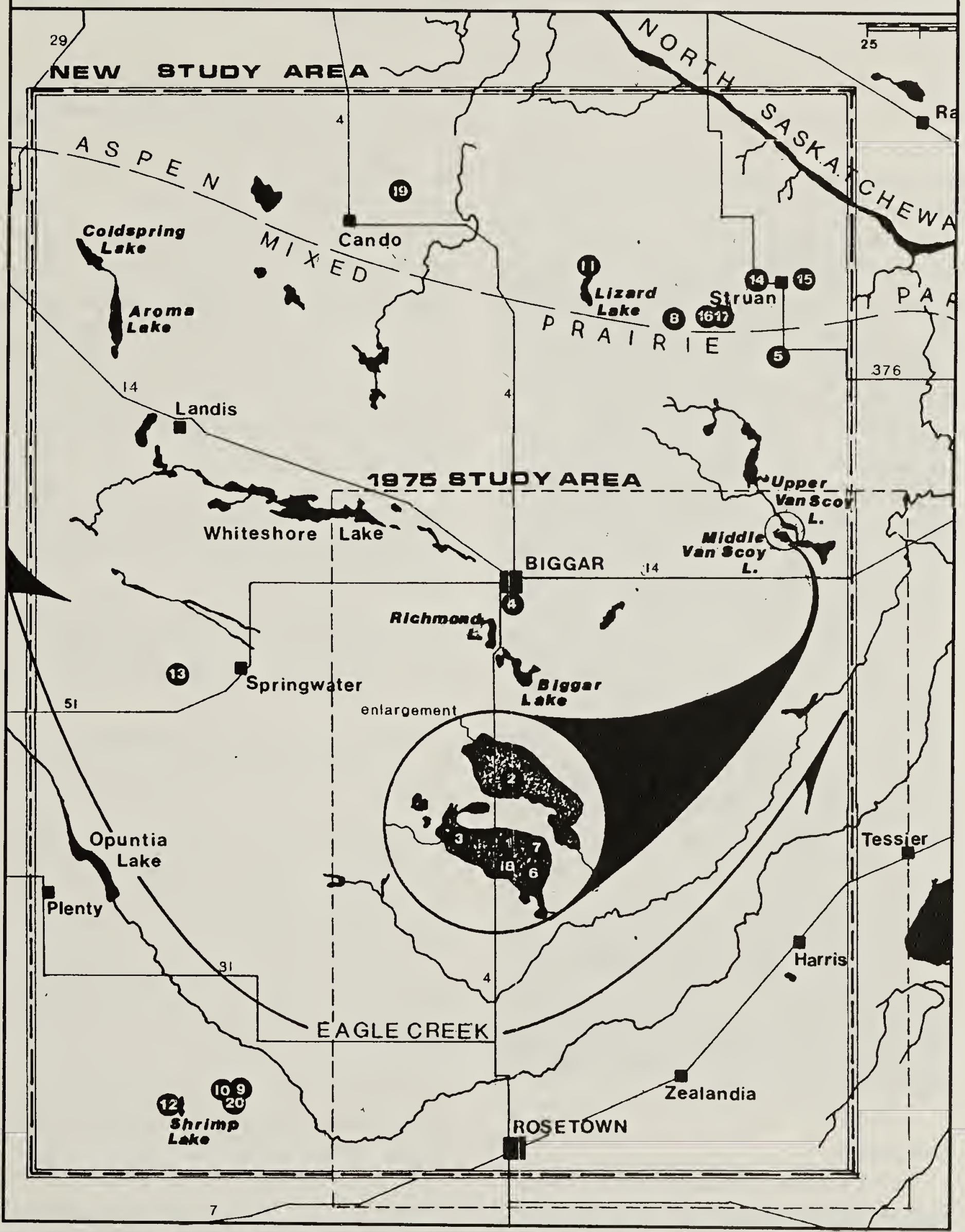

the north end of Lizard Lake (\#11) during the Biggar Breeding Bird Survey. On a 12 July return visit to the location of the 5 June breeding records, Robert Wapple found only three adults with three chicks. On the same day, two adults were found at the south end of Shrimp Lake $5 \mathrm{~km}$ farther west (\#12).
Thus, in less than two months, we located four active nests, plus two possible pairs in residence, at four different locations!

Except for Middle Van Scoy Lake, all marshes used for nesting in 1997 were dry in 1998 , or had water levels so low that 
existing marsh growth was unable to support breeding grebes. We still managed, however, to find Red-necked Grebes at four locations in June and July. On 11 June, Wayne Renaud and George Tosh found a pair milling near a stand of dense bulrushes on a large lake 6.5 $\mathrm{km}$ west of Springwater (\#13). During the Biggar Breeding Bird Survey on 23 June, one adult was on a marsh $3 \mathrm{~km}$ west of Struan (\#14) and a pair was found on another marsh $5 \mathrm{~km}$ east of Struan (\#15). On 17 July, Robert Wapple discovered two separate adults with broods of one and two young 6 $\mathrm{km}$ west and $3 \mathrm{~km}$ south of Struan (\#16, \#17). This last pair was approximately 3 $\mathrm{km}$ from the 3 June 1997 location.

Our luck continued in 2000. On 13,14 and 16 July, Wayne Renaud and Guy Wapple discovered a single adult Red-necked Grebe vocalizing near a bulrush marsh on the southeast corner of Middle Van Scoy Lake (\#18). On 17 July, the third record (and sixth confirmed breeding record for the area) consisted of an adult with 3 large young found by Wayne Harris and Sue McAdam on a 40-hectare marsh $5 \mathrm{~km}$ ne of Cando (\#19). On 18 July, Guy Wapple located a single adult, but without evidence of nesting, on a reservoir $5.6 \mathrm{~km}$ east of Shrimp Lake (\#20).

Thorough coverage of all known breeding sites was undertaken in July and August 2001 but no Red-necked Grebes were recorded, perhaps because many of these marshes were dry or water levels had dropped so severely that the habitat was no longer suitable for nesting Red-necked Grebes.

\section{Discussion}

We believe the breeding records presented here illustrate a significant, even if perhaps short-lived, southeastern expansion of the modern breeding range of the Red-necked Grebe into the mixed grassland biome of southwestern Saskatchewan. All of the breeding records presented here are outside the current breeding range as indicated by both Godfrey and Smith.'. In particular, the 5 June 1997 breeding record (28 km west of Rosetown), is located approximately 120 km southwest of the nearest known breeding record at Radisson Lake (Saskatoon Natural History files).

Why so many Red-necked Grebes suddenly began nesting in this area can only be a matter of speculation. It could have been directly related to the timing of the spring migration, which, in 1997, was unusually late. Species that normally nest farther north arrived later and may have attempted to breed in marshes south of their normal breeding range. These observations also suggest that, once established, Rednecked Grebes will return to their natal marshes, even if these locations fall outside of their regular breeding range.

1. GODFREY, W.E. 1986. Thc Birds of Canada. Rcvised Edition National Muscum of Natural Scicnces, Ottawa.

2. GOLLOP, J.B., J.F. ROY and R.V. FOLKER. 1963. Somc 1962 bird rccords for the Saskatoon District. Blue Jay 16 (1): 12-13

3. HAY, J. R. ct al. (eds). 2002. Birds of the Saskatoon Arca. Naturc Saskatchcwan, Regina In prep.

4. RENAUD, W. and D. RENAUD. 1975. The Birds of thc Rosctown-Biggar District, Saskatchcwan. Saskatchcwan Natural History Socicty Spccial Publication No.9. Rcgina

5. ROY, F. 1996. Birds of the Elbow. Saskatchcwan Natural History Socicty Spccial Publication No.21. Rcgina

6. SMITH, A. 1996. Atlas of Saskatchcwan birds. Saskatchcwan Natural History Socicty Spccial Publication No.22. Rcgina

7. WAPPLE, G.J. 1977. Additions to "Birds of the Rosctown-Biggar district, Saskatchcwan". Blue Jay 35:157-160. 